\title{
PENGUATAN PERILAKU HIDUP SEHAT DAN BERSIH DI MASA PANDEMI COVID-19
}

\author{
Agus Nugroho Setiawan \\ Program Studi Agroteknologi, Universitas Muhammadiyah Yogyakarta \\ agusns@umy.ac.id
}

\begin{abstract}
Pojok is one of the village of Wonokerto, Turi, Sleman, DIY, which is growing. The Pojok people realize that a good lifestyle will improve their health and a longer life expectancy, so they will continue to enhance their knowledge and insight about health. Some of the problems faced are the understanding and knowledge of the Pojok community about clean and healthy living behavior (PHBS) is still limited and has not been implemented as a whole. Family welfare program (PKK) activities related to clean and healthy living behavior and the number and skills of Health Cadres are still limited. Community Service activities were conducted in KKN PPM for six months, starting from January to June 2020. Community service was born with several stages, i.e., KKN student training, coordination, and socialization. The implementation of the field consisted of extension, training, facilitation, and assistance. The community service results show that the activity has been going well with several activities, i.e., coordination, socialization, counseling, training, and facilitation of supporting equipment, assistance, and monitoring and evaluation. The community of Pojok, Wonokerto, Turi gave a good response by participating in activities and implementing PHBS in their daily lives. The community feels they have gained insight, experience, and skills in the application of PHBS. The community service program of KKN PPM has provided more benefits; when the Covid-19 pandemic occurred, the community was ready to do a clean and healthy lifestyle
\end{abstract}

Keywords: Behavior, Clean, Covid-19, Healthy, PHBS

\begin{abstract}
Abstrak
Pojok merupakan padukuhan yang ada di Kalurahan Wonokerto, Kapanewon Turi, Kabupaten Sleman, DIY yang semakin berkembang. Masyarakat Pojok menyadari bahwa pola hidup yang baik akan meningkatkan taraf kesehatan dan usia harapan hidup yang lebih panjang, sehingga terus berusaha meningkatkan pengetahuan dan keterampilan tentang kesehatan. Beberapa permasalahan yang dihadapi adalah pengetahuan, wawasan, dan keterampilan masyarakat Padukuhan Pojok tentang perilaku hidup bersih dan sehat (PHBS) masih terbatas dan belum terimplementasikan secara menyeluruh. Selain itu, jumlah dan ketrampilan Kader Kesehatan, serta kegiatan PKK yang berhubungan dengan perilaku hidup bersih dan sehat masih terbatas. Dalam rangka mewujudkan PHBS di Padukuhan Pojok dilakukan Pengabdian Pada Masyarakat dalam bentuk Kuliah Kerja Nyata Pembelajaran dan Pemberdayaan Masyarakat (KKN PPM), yang dilakukan selama 6 bulan mulai bulan Januari-Juni 2020. Untuk mencapai tujuan, pengabdian pada masyarakat dilaksanakan dengan beberapa tahapan yaitu pembekalan mahasiswa KKN, koordinasi dan sosialisasi kepada masyarakat, implementasi lapangan yang terdiri dari kegiatan penyuluhan, pelatihan, fasilitasi, praktek dan pendampingan. Hasil pengabdian pada masyarakat menunjukkan bahwa kegiatan telah berjalan baik dengan beberapa kegiatan yaitu koordinasi, sosialisasi, penyuluhan, pelatihan dan fasilitasi peralatan pendukung, pendampingan, serta monitoring dan evaluasi. Masyarakat Padukuhan Pojok, Wonokerto, Turi memberikan tanggapan dengan berpartisipasi aktif mengikuti program pengabdian pada masyarakat dan menerapkan PHBS dalam kehidupan sehari-hari dengan baik. Masyarakat merasa mendapatkan wawasan, pengalaman dan keterampilan dalam penerapan PHBS. Program pengabdian pada masyarakat KKN PPM telah memberikan manfaat yang luas, ketika terjadi pandemi Covid-19, masyarakat sudah siap melakukan pola hidup bersih dan sehat.
\end{abstract}

Kata kunci: Bersih, Covid-19, Perilaku, PHBS, Sehat.

MARTABE : Jurnal Pengabdian Masyarakat|102 


\section{PENDAHULUAN}

Wonokerto merupakan salah satu kalurahan yang ada di Kapanewon Turi, Kabupaten Sleman, DIY, terletak di lereng selatan Gunung Merapi dengan jarak sekitar 4-6 km dari puncak (Anonim, 2019a).

Salah satu padukuhan yang ada di Kalurahan Wonokerto adalah Pojok. Padukuhan Pojok berada pada daerah dataran menengah pada ketinggian sekitar 500-600 m di atas permukaan laut dengan rerata curah hujan 3.908 $\mathrm{mm} /$ tahun dan keadaan tanah yang subur akibat abu vulkanik Gunug Merapi dengan struktur tanah berpasir. Lahan di Padukuhan Pojok sebagian besar berupa lahan pertanian dan sebagian yang lainnya dimanfaatkan untuk pemukiman penduduk dan pekarangan. Sebagaimana padukuhan yang lainnya yang ada di Kalurahan Wonokerto, sebagian warga Padukuhan Pojok menggantungkan hidup dari salak pondoh (Anonim, 2019b).

Penduduk di Pojok terdiri dari 630 jiwa Sebagian besar warga masyarakat Padukuhan Pojok berprofesi sebagai petani atau peternak, dan sebagian yang lainnya bekerja sebagai PNS, pedagang, buruh, dan sebagainya (Anonim, 2019b).

Semakin berkembangnya

Padukuhan Pojok memberikan konsekuensi terhadap pola hidup masyarakat. Masyarakat Padukuhan Pojok menyadari bahwa pola hidup yang baik akan meningkatkan taraf kesehatan dan usia harapan hidup yang lebih panjang, sehingga terus berusaha meningkatkan pengetahuan dan wawasan tentang kesehatan.

Kesehatan masyarakat mempunyai peran yang sangat penting dalam peningkatan kualitas sumber daya manusia, pembangunan ekonomi, dan penanggulangan kemiskinan, bahkan Indeks Pembangunan Manusia menempatkan kesehatan sebagai salah satu komponen utama pengukuran selain pendidikan dan pendapatan (Anonim, 2019c). Dalam jangka panjang, pembangunan kesehatan diarahkan untuk mencapai tujuan utama yaitu masyarakat mampu menolong dirinya sendiri dalam bidang kesehatan, peningkatan status gizi masyarakat, perbaikan kualitas lingkungan hidup untuk menunjang kesehatan, serta pengurangan angka kesakitan (morbiditas) dan kematian (mortalitas) (Anonim, 2019d).

Di Padukuhan Pojok sudah dilakukan beberapa kegiatan untuk meningkatkan wawasan dan pengetahuan masyarakat dalam bidang kesehatan melalui kegiatan penyuluhan oleh Puskemas Turi atau Kader Kesehatan, serta kegiatan PKK melalui Program Perilaku Hidup Bersih dan Sehat (PHBS). PHBS merupakan perilaku kesehatan yang dilakukan atas kesadaran diri sehingga dapat menolong dirinya pribadi di bidang kesehatan dan berperan aktif dalam kegiatan-kegiatan kesehatan di masyarakat. Setiap rumah tangga dianjurkan untuk melaksanakan semua perilaku kesehatan (Hidayat, 2017).

Meskipun di Padukuhan Pojok sudah ada usaha untuk mengarahkan masyarakat pada penerapan PHBS, namun ada beberapa permasalahan yang dihadapi, yaitu wawasan dan pengetahuan masyarakat Padukuhan Pojok tentang PHBS masih terbatas dan belum terimplementasikan secara menyeluruh, dan ketrampilan Kader Kesehatan serta kegiatan PKK yang berkaitan dengan PHBS masih terbatas. Pada umumnya kesadaran masyarakat untuk hidup sehat, serta mempertahankan atau memelihara kebersihan lingkungan di sekitarnya sudah ada, tetapi untuk 
mensosialisasikan ke anggota masyarakat lainnya tidak mudah (Supian et al., 2020).

Mendasarkan

pada

permasalahan yang ada, maka dilakukan usaha untuk meningkatkan pengetahuan, wawasan dan keterampilan masyarakat Padukuhan Pojok dalam menerapkan Perilaku Hidup Bersih dan Sehat (PHBS). Kegiatan tersebut dilakukan dalam bentuk pengabdian pada masyarakat Kuliah Kerja Nyata Pembelajaran dan Pemberdayaan Masyarakat (KKN PPM). Untuk mewujudkan tujuan tersebut, pengabdian pada masyarakat diperlukan motivasi dan komitmen yang tinggi dari seluruh masyarakat, persiapan yang matang, serta dukungan dari Pemerintah Kalurahan Wonokerto (Setiawan dan Wijayanti, 2019).

\section{METODE}

Untuk mencapai tujuan Program Pengabdian Pada Masyarakat di Padukuhan Pojok, KKN PPM dilakukan melalui tahapan pembekalan mahasiswa KKN, koordinasi dan sosialisasi kepada masyarakat, pelaksanaan KKN dan implementasi lapangan, dan Evaluasi Desa Unggulan (Gambar 1).

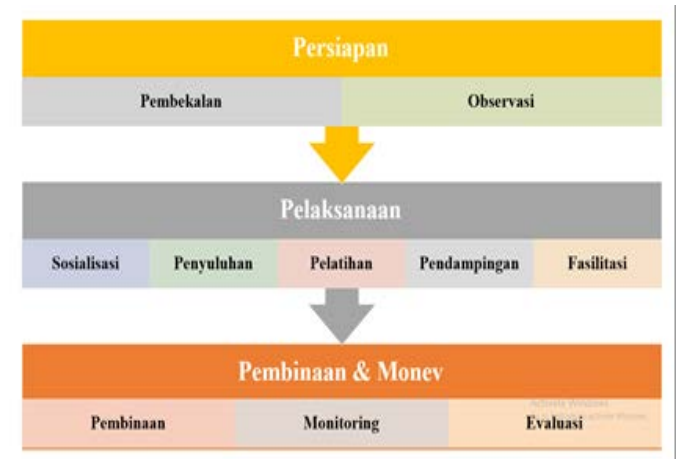

Gambar 1. Tahapan KKN PPM PHBS di Padukuhan Pojok

Pada tahapan persiapan, dilakukan koordinasi dan pembekalan kepada mahasiswa peserta KKN UMY, yang dilanjutkan dengan observasi lapangan ke Padukuhan Pojok. Tahapan pelaksanaan diawali dengan koordinasi dan sosialisasi kepada masyarakat Padukuhan Pojok, dilanjutkan dengan penyiapan bahan, peralatan, dan berbagai pendukung lainnya. Secara teknis, pelaksanaan di lapangan dilakukan melalui kegiatan penyuluhan, transfer teknologi, dan pelatihan.

Untuk

menjamin keberlangsungan KKN PPM dilakukan pembinaan dengan pendampingan, monitoring dan evaluasi.

\section{HASIL DAN PEMBAHASAN}

Pengabdian pada masyarakat KKN PPM Penguatan Perilaku Hidup Sehat Dan Bersih di Masa Pandemi Covid-19 di Padukuhan Pojok, Wonokerto, Turi telah dilakukan selama 6 bulan mulai bulan Januari-Juli 2020 dengan tahapan, yaitu persiapan, pelaksanaan, dan monitoring evaluasi.

Koordinasi dengan Pemerintah Kalurahan Wonokerto dilakukan pada bulan Desember 2019, untuk menginformasikan dan mendiskusikan rencana kegiatan KKN UMY, yang diterima oleh Kepala Desa dan Kasie Pelayananan Kalurahan Wonokerto. Hasil diskusi disepakati bahwa Pemerintah Kalurahan Wonokerto bersedia menerima KKN dari UMY. Selain itu, program pengabdian peda masyarakat dosen dan KKN UMY diharapkan dapat mendukung Evaluasi Desa Unggulan Wonokerto Tahun 2020 dengan tema sesuai masing-masing padukuhan, termasuk Padukuhan Pojok dengan tema PHBS.

Persiapan pelaksanaan KKN PPM dilakukan dengan koordinasi dan pembekalan mahasiswa peserta KKN pada akhir Desember 2019. Koordinasi bertujuan untuk ta'aruf (saling mengenal) antar mahasiswa dan antara 
mahasiswa dengan Dosen Pembimbing Lapangan (DPL), serta memberikan gambaran umum kegiatan KKN, kondisi Padukuhan Pojok dan dan kebutuhan informasi yang diperlukan dalam penyusunan laporan observasi. Untuk mendapatkan gambaran yang sesungguhnya tentang Padukuhan Pojok sebagai lokasi KKN, selanjutnya dilakukan beberapa kali survei dan observasi lapangan dengan didampingi oleh DPL dan bertemu dengan PIT. Kepala Dukuh, Ketua RW dan RT, Ketua PKK, serta ketua organisasi lainnya. Dalam observasi, mahasiswa mendapat penjelasan umum tentang Padukuhan Pojok, baik kondisi fisik, administratif pemerintahan, maupun kondisi sosial masyarakat (Gambar 2).

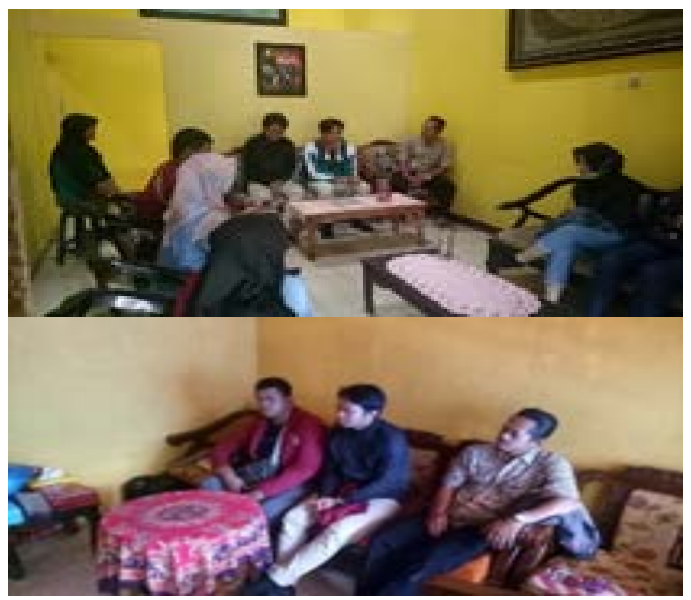

Gambar 2. Survei dan obsevasi KKN PPM

Hasil observasi selanjutnya digunakan untuk menyusun rencana program dan kegiatan KKN, yang dilakukan bersama antara DPL dengan mahasiswa. Hasil analisis dan rencana tersebut, selanjutnya didiskusikan dengan mitra yaitu Padukuhan Pojok, sampai tercapai kesepakatan untuk dapat dilaksanakan pada saat pelaksanaan KKN.

Pelaksanaan pengabdian pada masyarakat dan KKN PPM diawali dengan penerjunan dan penerimaan mahasiswa di Balai Kalurahan
Wonokerto, Turi pada awal Januari 2020. Dalam sambutannya, Pemerintah Kalurahan Wonokerto yang diwakili oleh Kasie Pelayanan menyampaikan pesan dan harapannya agar mahasiswa dapat berbaur dengan masyarakat, program KKN dirancang agar dapat memberikan manfaat bagi masyarakat Kalurahan Wonokerto, serta menjaga diri dan nama almamater (Gambar 3).

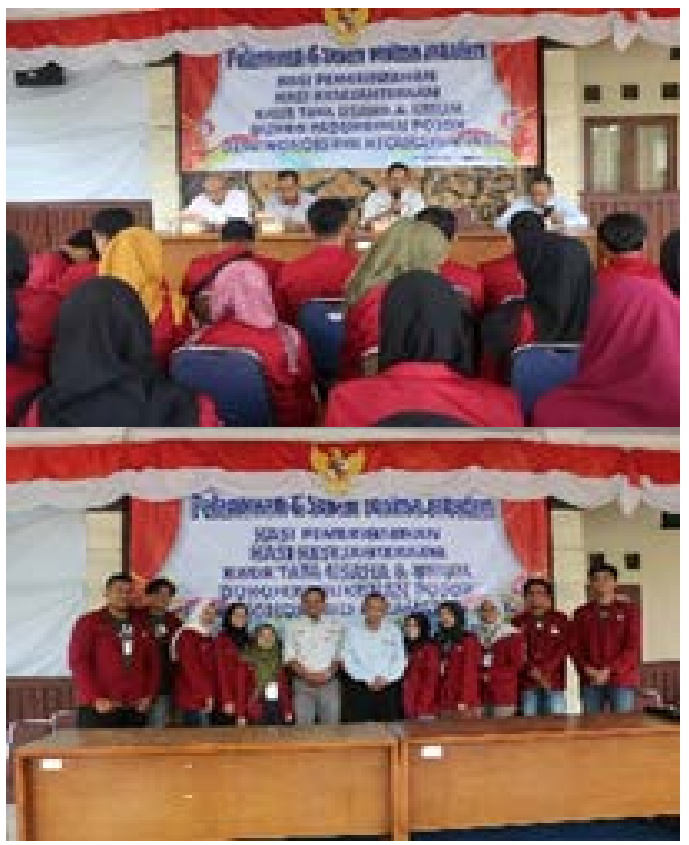

Gambar 3. Penerimaan mahasiswa KKN

Tahap awal implementasi kegiatan pengabdian pada masyarakat dan KKN adalah sosialisasi program KKN kepada masyarakat Padukuhan Pojok, yang dilakukan oleh dosen (DPL) dan mahasiswa KKN. Sosialisasi dilakukan dengan mengumpulkan perwakilan masyarakat Pojok yaitu Kepala Dukuh, Ketua RW dan Ketua RT, beserta pengurus dan anggota PKK, menjelaskan tentang berbagai hal yang akan dilakukan dalam pengabdian pada masyarakat, sehingga masyarakat memahami dan mempersiapkan diri sebagai penerima program (Gambar 4).

Untuk memberikan wawasan dan pengetahuan tentang pola hidup sehat dan bersih, dilakukan penyuluhan. 
Penyuluhan merupakan proses pembelajaran bagi masyarakat agar mampu menolong dan mengorganisasikan dirinya sebagai upaya untuk meningkatkan produktivitas, efisiensi usaha, pendapatan, serta kesejahteraannya (Permentan RI No. 03 Tahun 2018). Penyuluhan (promosi kesehatan) dapat meningkatkan pengetahuan setiap warga dan rumah tangga terhadap perilaku PHBS (Nelwan, 2019; Patilaiya dan Rahman, 2018). Penyuluhan kesehatan lingkungan dapat meningkatkan pengetahuan dan pelaksanaan kesehatan lingkungan (Hermawan dan Ikhsan, 2013).

Dalam penyuluhan dijelaskan bahwa tujuan utama PHBS di tingkat rumah tangga adalah tercapainya rumah tangga yang sehat. PHBS rumah tangga bertujuan untuk memberdayakan anggota rumah tangga agar tahu, mau dan mampu menjalankan perilaku hidup yang bersih dan sehat, serta berperan aktif dalam gerakan di tingkat masyarakat. Kebiasaan hidup bersih dan sehat harus selalu diterapkan terutama kepada para lansia karena lebih rentan terhadap berbagai macam penyakit (Yanti et al., 2020).

Penyuluhan dilakukan oleh Tim Pelaksana dan Kader PHBS kepada masyarakat baik secara masal dengan mengumpulkan warga maupun secara personal dengan mendatangi rumah warga (Gambar 4).

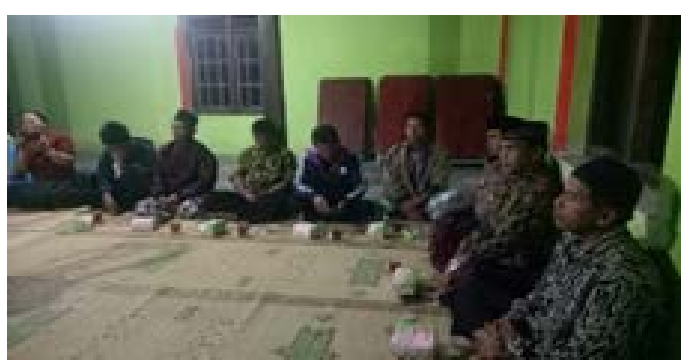

Gambar 4. Sosialisasi dan Penyuluhan PHBS di Pojok
Pelatihan dilakukan sebagai tindak lanjut penyuluhan yang sudah dilakukan sebelumnya, untuk memberikan keterampilan kepada masyarakat dalam melaksanakan PBHS. Pelatihan dilakukan secara berjenjang dengan terlebih dahulu dilakukan kepada Kader PHBS oleh Tim Faskes Puskesmas Turi dan Tim Pelaksana. Setelah dirasa cukup terampil, selanjutnya Kader PHBS memberikan pelatihan kepada masyarakat umumnya. Pelatihan ditekankan pada beberapa indikator PHBS pada tingkatan rumah tangga sebagai acuan untuk mengenali keberhasilan dari praktek perilaku hidup bersih dan sehat (Anonim, 2014; Anonim, 2016) (Gambar 5).

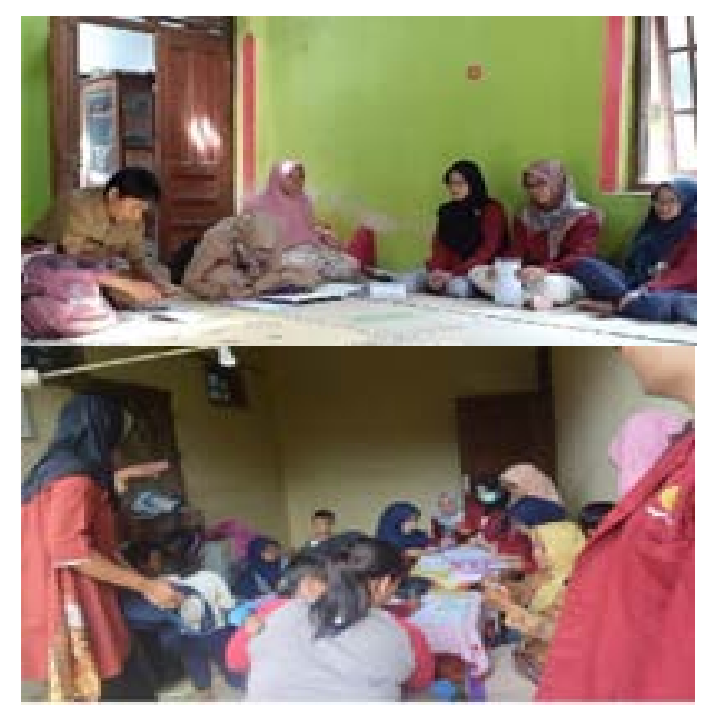

Gambar 5. Pelatihan PHBS di Pojok

Untuk mendukung pelaksanaan PHBS di Padukuhan Pojok juga dilakukan kebersihan lingkungan secara rutin dengan kerja bakti. Kegiatan ini bertujuan untuk menghilangkan lingkungan yang kumuh atau yang dapat berperan sebagai tempat berlindung atau sumber penyebab penyakit, dan menjadikan lingkungan bersih dan sehat. Dalam kegiatan ini, juga dilakukan penanaman berbagai jenis pohon buah dan bunga untuk 
menambah kenyamanan dan keindahan lingkungan (Gambar 6).

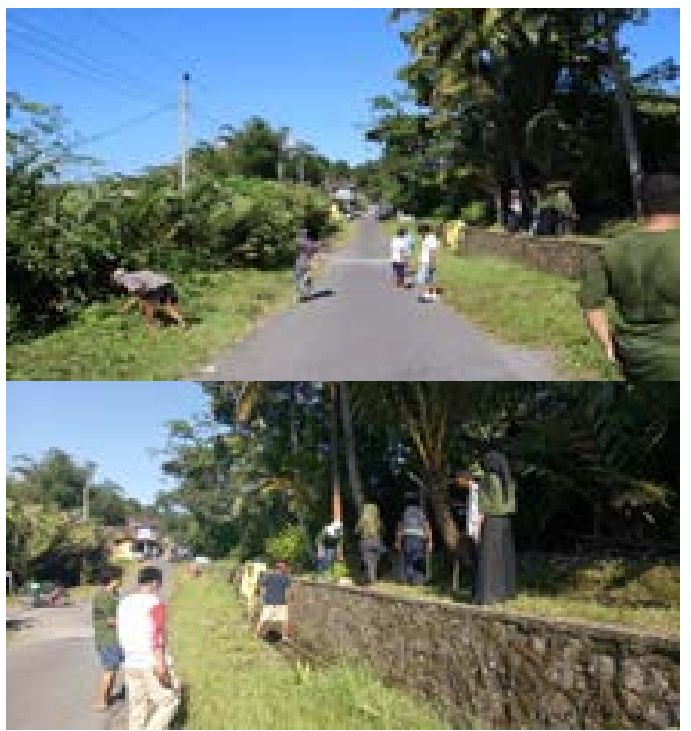

Gambar 6. Program Lingkungan di Pojok

Selain dengan melakukan penyuluhan dan pelatihan, untuk memberikan motivasi dan menginternalisasi PHBS kepada masyarakat dilakukan kampanye dengan membuat berbagai pesan dalam bentuk banner yang dipasang di tempattempat strategis, sticker dan pamflet yang dipasang di setiap rumah. Selain itu juga dilakukan fasilitasi dalam bentuk pengadaan beberapa tempat puntung rokok (asbak) di depan rumah sebagai sampel, dengan harapan dalam rumah terbebas dari asap rokok (Gambar 7).

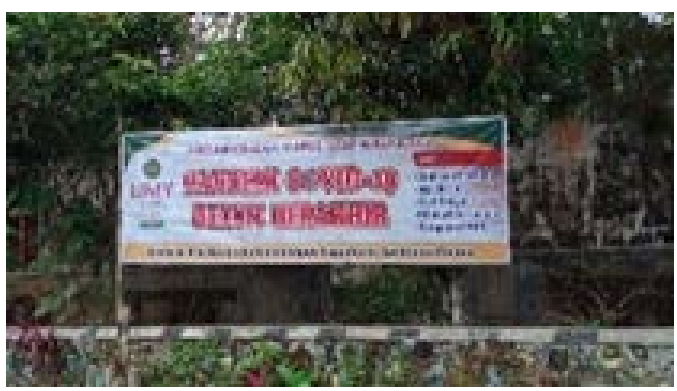

Gambar 7. Kampanye PHBS di Padukuhan Pojok

Keberhasilan penerapan PHBS ditunjukkan dengan perilaku masyarakat sehari-harinya. Untuk meningkatkan keberhasilan penerapan PHBS, dilakukan pembinaan berkelanjutan kepada masyarakat dengan kunjungan, monitoring dan evaluasi. Kunjungan dilakukan untuk mengetahui secara lebih jelas pelaksanaan PHBS oleh masyarakat. Dalam kunjungan juga dilakukan monitoring dan evaluasi terhadap pelaksanaan PHBS yang belum sesuai indikator yang sudah ditentukan. Guna mendukung PHBS di masa pandemi Covid-19 juga dibagikan masker bagi masyarakat (Gambar 8).
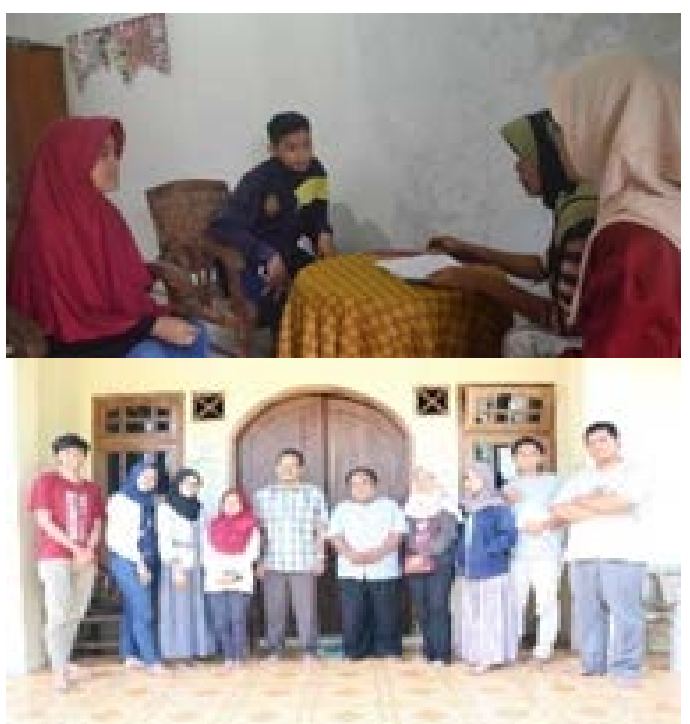

Gambar 8. Pembinaan dan Monev KKN

Hasil penerapan PHBS di Padukuhan Pojok sebenarnya diproyeksikan untuk menjadi wakil Kapanewon Turi mengikuti Evaluasi Desa Unggulan Tahun 2020 yang diselenggarakan oleh Pemerintah Kabupaten Sleman. Namun kegiatan tersebut tidak dapat dilaksanakan karena adanya pandemi Covid-19. Meskipun demikian, hasil pengabdian pada masyarakat KKN PPM di Padukuhan Pojok telah memberikan manfaat yang banyak bagi masyarakat. Ketika terjadi pandemi Covid-19, masyarakat Padukuhan Pojok sudah lebih siap 
karena sudah memahami dan terampil dalam menjalani pola hidup bersih dan sehat.

Secara keseluruhan kegiatan pengabdian pada masyarakat KKN PPM di Padukuhan Pojok sudah berjalan dengan baik. Masyarakat memberikan tanggapan dengan mengikuti kegiatan dan menerapan PHBS dalam kehidupan sehari-hari. Masyarakat merasa mendapatkan manfaat dengan bertambahnya pengetahuan, wawasan dan keterampilan dalam penerapan PHBS.

\section{SIMPULAN}

Dari program pengabdian pada masyarakat tentang Penguatan Perilaku Hidup Sehat dan Bersih di Masa Pandemi Covid-19 di Padukuhan Pojok, Wonokerto, Turi, Sleman, DIY dapat disimpulkan bahwa kegiatan telah berjalan dengan beberapa kegiatan yaitu pembekalan mahasiswa, koordinasi, sosialisasi, penyuluhan, pelatihan dan transfer ipteks, pendampingan, serta monitoring dan evaluasi. Masyarakat Padukuhan Pojok, Wonokerto, Turi berpartisipasi mengikuti kegiatan, merasa mendapatkan wawasan, pengalaman dan keterampilan, serta menerapkan perilaku hidup sehat dan bersih dalam kehidupan sehari-hari dengan baik. Meskipun Padukuhan Pojok, Wonokerto, Turi tidak jadi mewakili Kapanewon Turi dalam Evaluasi Desa Unggulan Bidang PHBS tingkat Kabupaten Sleman, namun program pengabdian pada masyarakat KKN PPM telah memberikan manfaat yang luas. Ketika terjadi pandemi Covid-19, masyarakat sudah siap melakukan pola hidup bersih dan sehat.

\section{UCAPAN TERIMA KASIH}

Ucapan terima kasih disampaikan kepada Rektor dan Kepala
LP3M UMY yang telah membantu penyediaan dana program pengabdian pada masyarakat KKN PPM ini, mahasiswa KKN UMY Tahun 2020 Kelompok 174 yang telah membantu pelaksanaan di lapangan dan seluruh masyarakat Padukuhan Pojok, Wonokerto, Turi, Sleman sebagai mitra yang telah berperan aktif dalam berbagai kegiatan.

\section{DAFTAR PUSTAKA}

Anonim. 2014. Perilaku Hidup Besih dan Sehat. https://lamongankab.go.id/ dinkes/phbs/. Diakses 15 Juni 2020

Anonim. 2016. PHBS. http://promkes. kemkes.go.id/phbs. Diakses 22 Juli 2020

Anonim. 2019a. Wonokerto, Turi, Sleman.

https://id.wikipedia.org/wiki/W onokerto,_Turi,_Sleman?veacti on $=$ edit\& section $=3$. Diakses 20 Juli 2020

Anonim. 2019b. Gambaran Umum. https://desawonokerto.wordpre ss.com/about/letakadministrasi/. Diakses 20 Juli 2020.

Anonim. 2019c. Kesehatan Masyarakat. http://penabulufoundation.org/ kesehatan-masyarakat/. Diakses 25 Juli 2020

Anonim. 2019d. Kesehatan. https://id.wikipedia.org/wiki/K esehatan. Diakses 25 Juni 2020

Hermawan, Y. dan K.N. Ikhsan. 2013. Pengaruh

Penyuluhan Kesehatan Lingkungan Terhadap Tingkat Pengetahuan dan Pelaksanaan Kesehatan Lingkungan SMP Negeri Tambaksari Kecamatan Tambaksari Kabupaten Ciamis. 
Agus Nugroho Setiawan. Penguatan Perilaku Hidup Sehat Dan Bersih Di Masa...

Bumi Lestari Journal of Environment 13 (1):166-173.

Hidayat, T. 2017. Pentingnya Perilaku Hidup Bersih dan Sehat. http://kotaku.pu.go.id/view/390 2/pentingnya-perilaku-hidupbersih-dan-sehat- Diakses 10 Juli 2020

Nelwan, J.E. 2019. Pengaruh Penyuluhan Kesehatan Terhadap Perubahan Pengetahuan Masyarakat Tentang Hipertensi Di Kota Manado. Journal Public Health Without Border 1 (2): 1-7.

Patilaiya, H.L. dan H. Rahman. 2018. Pemberdayaan Masyarakat Melalui Penyuluhan Perilaku Hidup Bersih Dan Sehat Untuk Meningkatkan Kualitas Kesehatan Masyarakat. Jurnal Pengabdian Dan Pemberdayaan Masyarakat 2 (2): 251-258.
Peraturan Menteri Pertanian Republik Indonesia No. 03 Tahun 2018 Tentang Pedoman Penyelenggaraan Penyuluhan Pertanian.

Supian, S., H. Hiwari, dan Subiyanto. 2020. Sosialisasi Pada Masyarakat Kabupaten Pangandaran Mengenai Bahaya Membuang Sampah Di Sungai. Martabe : Jurnal Pengabdian Kepada Masyarakat 3 (1): 2731.

Yanti, B., H. Priyanto, dan T. Zulfikar. 2020. Sosialisasi Waspada Infeksi Corona Virus Pada Lansia Di Panti Jompo Rumoh Seujahtra Geunaseh Sayang, Dinas Sosial Aceh. Martabe : Jurnal Pengabdian Kepada Masyarakat 3 (1): 67-72. 